\title{
The Analysis of the Structure, Behavior, and Performance of Tual Sagu Market in Kepulauan Meranti District
}

\begin{tabular}{|c|c|}
\hline \multicolumn{2}{|r|}{ Azmi $^{* 1}$ Syaiful Hadi ${ }^{2}$, \& Novia Dewi ${ }^{2}$} \\
\hline \multicolumn{2}{|c|}{$\begin{array}{l}{ }^{1} \text { Student of Masters of Agribusiness Department of the Faculty of Agriculture of } \\
\text { Universitas Riau, Indonesia } \\
{ }^{2} \text { Lecturers of Agribusiness Department of the Faculty of Agriculture of Universitas } \\
\text { Riau, Indonesia }\end{array}$} \\
\hline & * farizalazmi22@gmail.com \\
\hline Article Info & Abstract \\
\hline $\begin{array}{ll}\text { Received } & : 2019-07-19 \\
\text { Accepted } & : 2020-01-08 \\
\text { Published } & : 2020-01-28\end{array}$ & $\begin{array}{l}\text { This study is aimed at analyzing the 1) structure; 2) behavior; and 3) } \\
\text { performance of Tual sagu market in Kepulauan Meranti Regency. } \\
\text { This research was conducted using a survey method. Participants }\end{array}$ \\
\hline $\begin{array}{l}\text { Keywords: structure, behavior, } \\
\text { market performance }\end{array}$ & $\begin{array}{l}\text { and } 6 \text { factory owners). The analysis of Tual Sagu market was done } \\
\text { using descriptive, qualitative and quantitative methods. The findings } \\
\text { show that 1) the structure of Tual Sagu market in Kepulauan } \\
\text { Meranti Regency leads to a perfect competition market; 2) the } \\
\text { market behavior shows an imperfect competition market leading to } \\
\text { oligopsonism; and 3) the performance of Tual Sagu market in } \\
\text { Kepulauan Meranti Regency is not yet efficient. This is seen from } \\
\text { the fact that the margin marketing is greater at the merchant level } \\
\text { and the inequality of the benefits obtained. }\end{array}$ \\
\hline
\end{tabular}

\section{Introduction}

Riau Province is well recognised to have the potential of considerable and diverse natural resources. Land and forest resources are used as one of the capitals for development which can be aimed to increase the income and improve the welfare of Riau Province people. One of the new reserves of agricultural natural resources that needs to be optimized is the sago commodity. Sago is a kind of food that has the potential to overcome food insecurity in the future (Yunika, 2009). Sago is a local staple food that is well known in several regions including Maluku, Papua and Sulawesi (Ruhukail, 2012). Sago plants (Metroxylonsp) are potential enough to be developed as raw materials that can be processed into food and industrial materials (Timisela, 2006). Data from the Plantation Office of Kepulauan Meranti Regency (2016) indiocate that the area of sago plantations in Kepulauan Meranti Regency reaches 38.614 ha, which is 2.98 percent of the national sago plant area. The sago plantation in Kepulauan Meranti Regency with sago production reaches 202.062 tons/year and supplies raw materials for 67 sago refineries (The Central Bureau of Statistics of Kepulauan Meranti Regency, 2017).

Marketing activities are very important because they include various activities that enable goods to move to markets or to consumer areas. In the marketing sub-system, the actors generally have not properly considered the importance of implementing marketing functions in relation to achieving marketing efficiency (Saediman in Taridala, 2006). The role of marketing is very important where business owners are expected to be able to compete for the sustainability of their business. With market switching from the seller's market to the buyer's market, the sellers can determine prices based on their interest or inevitability where, like it or not, consumers will have to buy because there are no other products and/or the price increase far exceeds the marketing amount (Angipora, 1999).

The distribution pattern of sago marketing is from farmers to collectors or collectors to sago refineries and cooperatives so that sago commodities can move from the farmers to the consumers (Irawan, 1984). Meanwhile, according to Kusnawan and Wijoyo (2008), marketing is 
one of the activities that must be done by business owners to be able to develop and maintain business and earn profits. Marketing is a social and managerial process carried out by individuals or groups to meet needs and desires, where products of value are created, offered and exchanged. Marketing has several roles, one of which is formulating and implementing marketing programs based on the marketing mix. Marketing also manages harmonious relationships with customers and suppliers (Kotler, 2012)

Tual sagu (sago trunk) marketing in Tebing Tinggi Barat District is carried out through an intermediary agency before reaching the refinery. The decline in the Tual sagu prices is because the marketing chain is too long. The sago harvest by farmers is often forced to go through collectors, not directly sold to refineries due to the distance of the refinery location, inadequate transportation and the existence of a bonded-agreement between the sago farmers and the existing traders. This situation has led farmers to become the victims of price games. In addition, the marginal distribution of sago marketing is relatively uneven with a higher portion to the brokers (collectors and wholesalers). This unequal condition affects the farmers' motivation in managing their business and the quality of the sago produced.

Sago farmers in TebingTinggi Barat District sell their products to collectors and wholesalers. The collectors and wholesalers are from TebingTinggi Barat District and have agreed to buy the farmers' harvest. Farmers sell the sago plants in the form of Tual sagu (chopped sago trunk) to collectors at a price of IDR $1,741 / \mathrm{kg}$, and the collectors sell their tuals to large traders at a price of IDR $2,300 / \mathrm{kg}$. The difference leads to different margins and profits obtained by farmers if they sell the sago plant production to larger traders. This study is aimed at analyzing: 1) market structure, 2) market behavior, and 3) market performance of sago flour in Kepulauan Meranti Regency.

\section{Research Methodology}

\section{Research Time and Place}

This research was carried out in Kepulauan Meranti Regency specifically in Tebing Tinggi Barat District. This research site was selecteddeliberately using purposive sampling technique. Therefore, considering that Tebing Tinggi Barat District is one of the sago flour agroindustry centers, then this district was chosen as the research site. The research was conducted from October 2018 to January 2019.

\section{Sampling Technique}

The respondents in this study were 27 sago farmers, 6 collectors, 6 refineries or sago agroindustry producers. The sampling technique was purposive sampling. Sago farmer respondents were selected based on their criteria of which they should have a land area of more than one hectare. All six sago refinaries were studied.

\section{Data Collection Technique}

The primary data were obtained by conducting in-depth interviews with the respondents and using a structured questionnaire. Meanwhile, the secondary data were obtained from related agencies and reference sources that support this research.

\section{Data Analysis}

The analysis of the Tual sagu marketing in Kepulauan Meranti Regency, including the analyses of market structure, market behavior and market performance was done in accordance with SCP (Structure, Conduct and Performance) models.

\section{Market Structure}

The market structure was analyzed descriptively and quantitatively. The descriptive market structure analysis was done to analyze the market structure by explaining the number of market actors and barriers to market entry. The quantitative market structure analysis was done by calculating the concentration ratio, market share, and Herfindhal index value. 


\section{Concentration ratio}

According to Anindita and Baldina (2016), concentration ratio is a comparison between the number of goods purchased by certain traders and the number of goods sold by all traders, then multiplied by $100 \%$. The ratio concentration formula is:

$$
\mathrm{Kr}=\frac{\text { the number of tual sagu purchased by sago traders }}{\text { the number of tual sagu sold by all traders }} \times 100 \%
$$

1. If there is one trader who has a $\mathrm{Kr}$ value of at least $95 \%$ then the market is said to be a monopsony market,

2. If there are four traders having a $\mathrm{Kr}$ value of at least $80 \%$ then the market is said to be a high concentration oligopsonic market,

3. $\mathrm{f}$ there are eight traders having a $\mathrm{Kr}$ value of at least $80 \%$ then the market is said to be a moderate concentration oligopsonic market (Hay and Morris in Yuprin, 2009).

\section{Market share}

The market share for each marketing institution can be formulated as follows:

$$
M S_{i}=\frac{S_{i}}{S_{\text {tot }}} \times 100
$$

Wehre:

$\mathrm{MS}_{\mathrm{i}}=$ traderi's market share $(\%)$

$\mathrm{S}_{\mathrm{i}}=$ traderi's sales $(\mathrm{Rp})$

$\mathrm{S}_{\mathrm{tot}}=$ total sales of all traders $(\mathrm{Rp})$

\section{Herfindhal index}

The calculation formula for the Herfindhal index is as follows:

$$
\mathrm{IH}=(\mathrm{S} 1)^{2}+(\mathrm{S} 2)^{2}+\ldots .+(\mathrm{Sn})^{2}
$$

Where:

$\mathrm{S} 1, \mathrm{~S} 2, \ldots \mathrm{Sn}=$ The share of tual sagu purchases from traders $1,2, \ldots, \mathrm{n}$

With criteria:

If $\mathrm{IH}=1$, the tual sago market leads to the monopsony market.

If $\mathrm{IH}=0$, the tual sago market leads to perfect competition.

If $0<\mathrm{IH}<1$, the tual sago market leads to the oligopsonic market.

\section{Market Behavior}

According to Kuncoro (2007), market behavior is interpreted as a pattern of responses made by companies to achieve their objectives within the scope of industrial competition. The reaction between one and another company is shown in the form of selling prices and product promotion (advertising). Market behavior is used to determine everything related to the company's operations. This type of market strategy is carried out by market actors and their competitors. Each action carried out by companies in the industry has its own characteristics as a step to penetrate the market (Teguh, 2006). Market behavior is analyzed quantitatively by (1) correlation analysis and (2) analysis of price transmission elasticity. 
The Analysis of the Structure, Behavior, and Performance of Tual Sagu Market in Kepulauan Meranti District

$$
r=\frac{\left\{n \sum X i Y i-(\Sigma X i)(\Sigma Y i)\right\}}{\sqrt{\left\{\sum X i^{2}-(\Sigma X i)^{2} Y n \Sigma Y i^{2}-(\Sigma Y i)^{2}\right\}}}
$$

Where:

$\mathrm{r} \quad=$ The correlation between tual sagu prices at the factory level and tual sagu prices at the farm level.

$\mathrm{n}=$ The number of sample.

$\mathrm{Xi}=$ tual sagu prices at the factory level (IDR/Kg).

$\mathrm{Yi}=$ tual sagu prices at the farm level (IDR/Kg).

Sugiarto in Setiawan (2011) states that determining the degree of the relationshipcloseness in the price correlation analysis can be done by the guidelines as in the table below:

Table 1. Level of relationship in correlation analysis

\begin{tabular}{lll}
\hline $\boldsymbol{r}$ value & \multicolumn{1}{c}{ Correlation Criteria } & Market Integrity \\
\hline 0 & No Correlation & Imperfect \\
$0-0,5$ & Weak Correlation & Imperfect \\
$>0,5-0,8$ & Moderate Correlation & Imperfect \\
$>0,8-1$ & Strong Correlation & Imperfect \\
1 & Perfect & Perfect \\
\hline
\end{tabular}

Price transmission analysis is aimed at finding out the market performance between the producer level market and the consumer level market (Azzaino, 1981). The price transmission elasticity $(\mathrm{Et})$ is obtained through the following equation.

Where:

$$
\mathrm{Et}=\frac{1}{b_{1}} \cdot \frac{p r}{p f}
$$

Et $=$ price transmission elasticity

$\mathrm{Pf}=$ price at the consumer level

$\operatorname{Pr}=$ price at the producer level

$\mathrm{b}_{1}=$ regression coefficient

Price transmission elasticity can be determined by one of these three criteria:

1. If Et $=1$, it means that the rate of change in prices at the farm level is the same as the rate of change in prices at the factory level;

2. If Et> 1, the rate of change in prices at the farm level is greater than the rate of change in prices at the factory level; and

3. If Et $<1$,it means the rate of change in prices at the farm level is smaller than the rate of price change at the factory level. This shows the power of monopsonies or oligopsonies in marketing institutions so that price increases are only enjoyed by factories. These parameters can be estimated using a simple linear regression model as in the equation below:

$$
P f=b_{0}+b_{1} P_{r}+e_{1}
$$

Where:

$\mathrm{Pf}=$ prices at the farm level (IDR/Kg)

$\operatorname{Pr}=$ prices at the collector and factory level (IDR/Kg)

bo $=$ constanta 
$\mathrm{b}_{1}=$ regression coefficient

e1 = galat

\section{Market Performance}

\section{Marketing Margin}

In developing countries, weak infrastructure, transportation, and communication increase the number of marketing margins due to the high cost of delivering local commodities to market locations for consumption (Mumbeya, 2011). According to Sudiyono (2001), the marketing margin components consist of: (1) the costs required by marketing institutions to perform marketing functions called marketing costs or functional costs, and (2) marketing agency profits.

$$
\mathrm{M}=\sum_{j=1}^{m} M j=\sum_{j=1}^{m} \sum_{i=1}^{n} C i j+\sum_{j=1}^{m} P j
$$

Where:

$\mathrm{M}=$ marketing margin (IDR/kg)

$\mathrm{Mj}=$ marketing margin $(\mathrm{IDR} / \mathrm{kg})$ of marketing agency $\mathrm{j}(\mathrm{j}=1,2, \ldots, \mathrm{m}) ; \mathrm{m}$ : number of marketing involved.

$\mathrm{Cij}=$ marketing costs number $\mathrm{i}(\mathrm{IDR} / \mathrm{kg})$ to marketing agencies number $\mathrm{j} ;(\mathrm{i}=1,2, \ldots \mathrm{n})$ and $\mathrm{n}$ the number of financing types.

$\mathrm{Pj}=$ agency profit margin of marketing number $\mathrm{j}(\mathrm{IDR} / \mathrm{kg})$.

\section{Price share received by farmers}

The formula for finding priceshares at the farm level is as follows:

$$
\mathrm{SPf}=\frac{\operatorname{Pf}}{\operatorname{Pr}} \times 100 \%
$$

Where:

SPf $=$ price share at the farm level

$\mathrm{Pf}=$ price at the farm level

$\operatorname{Pr}=$ price at the final consumer level

\section{Cost share and Profit share}

$$
\begin{aligned}
& \mathrm{SBi}=\frac{\mathrm{Bi}}{(\mathrm{Pr}-\mathrm{Pf})} \times 100 \% \\
& \mathrm{SKi}=\frac{\mathrm{Ki}}{(\mathrm{Pr}-\mathrm{Pf})} \times 100 \%
\end{aligned}
$$

Where:

$\mathrm{SBi}=$ Cost share of marketing agency number $\mathrm{i}$

Ski $=$ Profit share of marketing agency number $\mathrm{i}$

$\mathrm{Bi}=$ Marketing costof marketing agency number $\mathrm{i}$

$\mathrm{Ki}=$ Profitof marketing agency number $\mathrm{i}$

$\operatorname{Pr}=$ Tual sagu price at the factory level (IDR/kg)

Pf = Tual sagu price at the farm level (IDR/kg) 


\section{Findings and Discussions}

\section{Descriptive Analysis of Market Structure of Tual Sagu Market}

\section{The Number of Market Actors}

There were were 27 farmers number chosen as respondents at tual sagu market in Tebing Tinggi Barat District. There were two types of marketing institutions; collectors and wholesalers or refineries. The collectors in Tebing Tinggi Barat District chosen as respondents were 6 people and the large traders or refineries chosen as respondents were 6 people. Market actors of farm owners or tual sagu have a relatively larger number of producers compared to the number of traders who buy tual sagu from farmers. This causes the marketing institutions in Tebing Tinggi Barat District (collectors) to compete in purchasing tual sagu from farmers. Similarly, large traders or refineries are also competing in the purchase of tual sagu from the collectors.

\section{Marketing Channel}

The process of product distribution is an integral part of the post-production of goods by a company or industry (Irawan\&Wijaya, 2001). Based on the results of observations and interviews with respondents in TebingTinggi Barat District, in marketing, there are 2 types of marketing channels of tual sago distribution from farmers to refineries, but the most efficient one used in TebingTinggi Barat District is the first channels, i.e.:

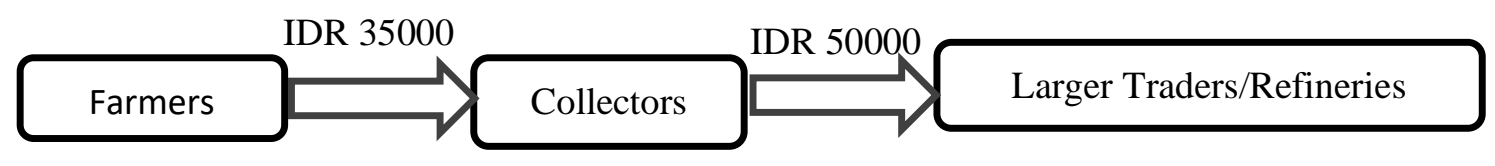

Figure 1. Percentage of marketing channel

This study has found that there is one marketing channel of Tual sagu at the research location. The percentage of farmers using this marketing channel is 27 people (100\%) or almost all of the respondent farmers sell their tuals to collectors first, and then collectors sell the Tual sagu to refineries. The percentage of farmers who use marketing channel 1 is 100 percent, because the farmers as respondents in this research think that using other marketing channels will extend the distribution time of the Tual sagu. The farmers just want to shorten their time and ease their job. They want to get it done without having to incur other costs. That is why most farmers in the research location use only one channel, and they prefer this channel because they interact more often with the collectors.

\section{Market Exit Barriers}

The obstacle that occurs to farmers in Tebing Tinggi Barat District is that the majority of farmers have an attachment to one of the collectors. The farmers as respondents in this study stated that they had an attachment to the traders who bought their tual sagu products because farmers had prior agreements such as collectors who had helped them loans, for instance, or often helped farmers in various ways especially financial problems with agreements that farmers have to sell their tual sagu only to that collectors. Meanwhile, the farmers who do not have attachments to certain collectors, they are free to sell to any collectors, as long as the prices set by the collectors are beneficial to them.

\section{Quantitative Analysis of the Structure of the Tual Sagu Market in Tebing Tinggi Barat District}

The average market share and the concentration ratio of the collectors in Tebing Tinggi Barat District is respectively 0.17 and $16.67 \%$, which means that there is no one trader who has a concentration ratio above $95 \%$. 
Table 2. Market Share Value and Concentration Ratio of Four Collectors with the Biggest Purchase Volume in TebingTinggi Barat District

\begin{tabular}{clccc}
\hline No & \multicolumn{1}{c}{ Collectors } & $\begin{array}{c}\text { Purchase Volume } \\
\text { (Kg/Month) }\end{array}$ & $\begin{array}{c}\text { Concentration } \\
\text { Ratio (\%) }\end{array}$ & Market Share \\
\hline 1 & H. Johan & 3.350 & 44,37 & 0,44 \\
2 & H. Lukman & 1.600 & 21,19 & 0,21 \\
3 & Jang & 950 & 12,58 & 0,13 \\
4 & Sapar & 1.050 & 13,97 & 0,14 \\
\hline \multicolumn{2}{r}{ Total } & $\mathbf{6 . 9 5 0}$ & $\mathbf{9 2 , 1 1}$ & $\mathbf{0 , 9 2}$ \\
\hline
\end{tabular}

Table 2 shows that the market share and the concentration ratio of the four collectors with the largest purchase volume in TebingTinggi Barat District are respectively 0.92 and $92.11 \%$. This means that from the four collecting traders, the concentration value above $80 \%$ shows that the collectors have a high level of power in influencing the Tual sagu market. It is said to be strict oligopoly if the merger of four traders has $60-100 \%$ in the market share, whereas from the concentration ratio, the four collectors have a $\mathrm{Kr}$ value above $80 \%$, thus the market is said to be a high concentration oligopsonic market.

The value of market share and concentration ratio of wholesalers or refineries in Tebing Tinggi Barat District can be seen in Table 3.

Table 3. Market Share Value and Concentration Ratio of All Wholesalers or Refineries with the Biggest Purchase Volume in TebingTinggi Barat District

\begin{tabular}{clccc}
\hline No & Wholesaler/Refienry & $\begin{array}{c}\text { Purchase Volume } \\
(\mathbf{k g} / \text { Month) }\end{array}$ & $\begin{array}{c}\text { Concentration } \\
\text { Ratio }(\%)\end{array}$ & $\begin{array}{c}\text { Market } \\
\text { Share }\end{array}$ \\
\hline 1 & Amir/SaguHarapan & 33,350 & 19 & 0,19 \\
2 & Alinan & 20,800 & 12 & 0,12 \\
3 & Syarifudin & 29,150 & 17 & 0,17 \\
4 & Apang & 25,000 & 14 & 0,14 \\
5 & Kharudin & 31,250 & 18 & 0,18 \\
6 & Adi Anto & 35,400 & 20 & 0,20 \\
\hline \multicolumn{2}{c}{ Total } & 174,950 & 100 & 1,00 \\
\hline & Average & 29,158 & 17 & 0,17 \\
\hline
\end{tabular}

According to Hay and Morris (1991), if there is one trader who has a concentration ratio of $95 \%$ at minimum, then the market structure is said to be a monopsonist market; if there are some traders where the concentration of four large traders is at least $80 \%$, the market structure is said to be high concentration oligopsonies; and if the concentration ratio of six wholesalers is at least $80 \%$, the market is said to be a moderate concentration of oligopsonist market. Table 3 shows the average market share and the concentration of the ratio of wholesalers or refineries in Tebing Tinggi Barat District are respectively 0.17 and $17 \%$. This means that there is no trader who has a concentration ratio above $95 \%$.

Market share and concentration ratio of the merger of four large traders or refineries with the largest sago tual purchase volume in Tebing Tinggi Barat District can be seen in the table 4 .

Table 4.Market Share Value and Ratio Concentration of Four Wholesalers or Refineries with the Biggest Purchase Volume in TebingTinggi Barat District

\begin{tabular}{clccc}
\hline No & Wholesaler/refinery & $\begin{array}{c}\text { Purcahse Volume } \\
\text { (kg/Month) }\end{array}$ & $\begin{array}{c}\text { Concentration } \\
\text { Ratio (\%) }\end{array}$ & $\begin{array}{c}\text { Market } \\
\text { Share }\end{array}$ \\
\hline 1 & Amir/SaguHarapan & 33,350 & 19 & 0,19 \\
2 & Syarifudin & 29,150 & 17 & 0,17 \\
3 & Kharudin & 31,250 & 18 & 0,18 \\
4 & Adi Anto & 35,400 & 20 & 0,20 \\
\hline & Jumlah & 129,150 & 74 & 0,74 \\
\hline
\end{tabular}

Table 4 shows that the market share and concentration ratio of four wholesalers or refineries with the largest purchase volume in TebingTinggi Barat District are respectively 0.74 
and $74 \%$. This means that the four collectors obtained concentration values below $80 \%$. This indicates that large traders or refineries have a moderate level of power in influencing the Tual sagu market. It is said to be tight oligopoly if the merger of four traders has $60-100 \%$ in the market share, while viewed from the concentration ratio of four collectors, the $\mathrm{Kr}$ value is below $80 \%$, meaning the market is said to be a moderate concentration oligopsonic market.

Herfindhal index values in Tebing Tinggi Barat District can be seen in tebel 12 below:

Table 5. Herfindhal Index Valuein TebingTinggi Barat District

\begin{tabular}{clcc}
\hline No & & Trader & Herfindhal Index \\
\hline 1 & Collectors & & 0,2801 \\
2 & Wholesalers/Refineries & 0,1715 \\
\hline
\end{tabular}

Table 5 indicates that the Herfindhal Index value in Tebing Tinggi Barat District is 0.2801 for collector traders, meaning that the herfindhal index value in Tebing Tingi Barat District is greater than 0 and smaller than 1. Thus, the tual sagu market formed in Tebing Tingi Barat District is an oligopsonist market. Meanwhile, the herfindhal index value for large traders or refineries is 0.1715 . This means that it is greater than 0 and smaller than 1 , then the tual sagu market formed is an oligopsonic market.

The quantitative analysis of tual sagu market structure in Tebing Tingi Barat District indicates that the structure at the level of traders and wholesalers or refineries is leading to a high concentration oligopsonic market. This means that collectors in Tebing Tinggi Barat District have high power in influencing the market and causing bargaining positions of farmers in a weak condition; farmers are always in the price-taker position.

\section{Descriptive Analysis of Tual Sagu Market Behavior}

Market behavior is how market participants i.e. producers, consumers and marketing institutions adjust to the sales and purchasing situations that occur (Prasetyo, 2007). Market behavior is not always constant; it will always change. The analysis used includes pricing and market institutional systems.

\section{The Application of Tual Sagu Pricing}

Price is an important factor in an industry. Market behavior encourages collaboration in pricing. There are two reasons for this. First, price is the most effective and dangerous weapon in competition. Second, price is a critical part that must be controlled (Kirana, 2003).

The existing farmers know information about tual sagu prices when they want and sell their tual sagu to the collectors. The price of tual sagu in Tebing Tinggi Barat District is different each month. This is because farmers get information about the selling price of tual sagu from the collectors, therefore they can only accept the selling price of their sagu from the collectors and cannot negotiate prices for the prices received from the collectors. This is because the rates they have are also obtained from the price of the large traders or refineries. Meanwhile, in determining tual sagu selling prices, the larger traders or refineries obtain it from the selling price of sagu flour in the market, which is from Cirebon. The low share price received by farmers is due to the fact that tual sagu prices are determined by large traders, where in this case, larger traders tend to have the strength of the bargaining position and that farmers are only price takers. This is in line with what Navia S, Suwandari A, Ridjal J (2014) found out, that the determination of the price of cassava is largely determined by the market mechanism, although ultimately it is actually an agreement between farmers and traders. The second indicator of whether or not there is cooperation between traders (cassava traders) is that the traders do not cooperate in marketing the cassava. This can be seen from the behavior of traders in the fulfillment of cassava raw materials that are going to be sold.

The price of the tual sagu in its selling process received by farmers is rather small, in accordance with the facts on the field that most tual sagu prices received by farmers are without 
incurring other costs; IDR23,000-25,000 per tual. Such small price is also influenced by the farmers themselves because many of them have debts from the collectors. Meanwhile, collectors who sell their tual sagu to the wholesalers or refineries get quite a higher price than farmers do; at a price of IDR42,000-50,000. This is because, in the process of buying the farmers' tual sagu, collectors also incur costs for logging, assembling, collecting, and delaying and transport costs. Furthermore, when it is seen from wholesalers or refineries who buy tual sagu from collectors, in determining the prices, the large traders or refineries also see the market price of sago flour produced by refineries. The price of sago flour in the market reaches a price of IDR5,000 per kilogram.

\section{Quantitative Analysis of Tual Sagu Market Behavior}

\section{Correlation Analysis}

Based on the results of the correlation analysis between prices at the farm level and the at the refinery level each month, the price correlation value at the farmer level in Tebing Tinggi Barat District was 0.344 for farmers who sell the tual sagu. Referring to the criteria for the relationship of two variables based on the correlation coefficient value (Sugiarto in Setiawan, 2011), if the correlation value between two variables is between $0.1-0.5$, it is said that there is a moderate relationship between the two variables. It means that the correlation between the price at the farm level and of which at the refinery level in Tebing Tinggi Barat District has a weak correlation.

\section{Analysis of Price Transmission Elasticity}

$$
\mathrm{Et}=\frac{1}{0,286} \cdot \frac{49,667}{25,963}
$$

The Et value is 6,688, thusEt $>1$ or Et $>6,688$ meaning that the rate of change of tual sagu prices at the farm level is greater than of which at the refinery level.

\section{Market Performance}

\section{Marketing Margin}

Marketing margins can reflect marketing efficiency in marketing activities carried out by the marketing institutions involved. Marketing margins can be seen in table 6 below:

Table 6. Marketing Margin, Marketing CostandMarketing Agencies' Profit at Marketing ChannelI in Tebing Tinggi Barat District in 2018

\begin{tabular}{|c|c|c|}
\hline \multirow{2}{*}{ No } & \multicolumn{2}{|c|}{ Marketing Channel } \\
\hline & Description & Average Price of Tual sagu (IDR/Kg) \\
\hline 1 & Farmer & \\
\hline \multirow{13}{*}{2} & Selling Price & 1.741 \\
\hline & Collector & \\
\hline & Buying Price & 1.741 \\
\hline & Selling Price & 2.300 \\
\hline & Margin & 559 \\
\hline & Marketing Cost & \\
\hline & a. Logging & 111 \\
\hline & b. Collecting & 134 \\
\hline & c. Transport Cost & 50 \\
\hline & d. Assembling & 37 \\
\hline & e. Delaying & 185 \\
\hline & The Total of Marketing Cost & 517 \\
\hline & Profit & 42 \\
\hline \multirow[t]{5}{*}{3} & Large Traders/Refineries & \\
\hline & Buying Price & 2.300 \\
\hline & Selling Price & 5.000 \\
\hline & Margin & 2.700 \\
\hline & Marketing Cost & \\
\hline
\end{tabular}


The Analysis of the Structure, Behavior, and Performance of Tual Sagu Market in Kepulauan Meranti District

\begin{tabular}{|c|c|c|}
\hline \multirow{2}{*}{ No } & \multicolumn{2}{|c|}{ Marketing Channel } \\
\hline & Description & Average Price of Tual sagu (IDR/Kg) \\
\hline & a. Transportation & 769 \\
\hline & b. Unloading & 48 \\
\hline & c. Loading & 48 \\
\hline & d. Credits & 10 \\
\hline & e. Employees' Salary & 88 \\
\hline & f. Machinary Service & 332 \\
\hline & g. Engine Fuels & 38 \\
\hline & h. Packing & 333 \\
\hline & i. Tax & 8 \\
\hline & j. $200 \mathrm{~kg}$ shrinkage from 26 tons & 8 \\
\hline & The Total ofMaketing Cost & 1982 \\
\hline & Profit & 718 \\
\hline 4 & The Total of Margin & 3.259 \\
\hline 5 & The Total of Marketing Cost & 2.499 \\
\hline 6 & The Total of Marketing Agencies' Profit & 760 \\
\hline
\end{tabular}

The data in Table 6 show that the marketing margin in marketing channel I was obtained at IDR $559 / \mathrm{kg}$ at the level of the collectors and IDR $2,700 / \mathrm{kg}$ at the level of wholesalers/refineries. The total marketing margin on marketing channel I is IDR $3.259 / \mathrm{kg}$. This margin is obtained from the average selling price of farmers estimated from the purchase price of the collector at a price of IDR $1,741 / \mathrm{kg}$, then the collector sells at a price of IDR 2,300/kg to large traders. Next, the large traders sell at a price of IDR 5,000/kg in the form of sago flour. In the marketing channel I, the total marketing costs at the level of the collector is ar IDR $517 / \mathrm{kg}$, the marketing costs at the level of the collectors are obtained from the costs of logging, collecting, transporting, assembling and delaying. Whereas at the wholesaler/refinery level, the total marketing costs is IDR 2,499/kg. The marketing costs at the level of large traders are obtained from transportation costs, unloading costs, loading costs, credit fees, employee salaries, engine maintenance costs, machine fuels, packaging costs, taxes, and shrinkage of $200 \mathrm{~kg}$ of $26,000 \mathrm{~kg}$ sago flour.

This is in line with Wati (2015) who states that the shorter the marketing channel, the more efficient marketing is carried out. The advantage of marketing sagu commodities at the wholesaler level is IDR $760 / \mathrm{Kg}$. The profit is obtained from the calculation of the total margin minus the total marketing costs of large traders, while the profits obtained by the collector are not very big, only IDR $42 / \mathrm{kg}$. The profit is obtained from the margin minus the total marketing costs of the collector.

\section{Price Share received by farmers}

The size of the portion received by the farmers is calculated by looking at the comparison between the price portion for the farmer and the price for the wholesaler or refinery. From the results of the study, it was found that the portion received by farmers in the marketing channel I was $34.82 \%$ with revenues of IDR $1,741 / \mathrm{kg}$ (Table 6). In channel I, there are 2 marketing institutions involved, i.e. collectors and wholesalers. This is in accordance with the theory proposed by Sudiyono (2002) stating that the indicator which can be used to determine marketing efficiency is the marketing margin. The greater the marketing margin, the more inefficient the marketing is.

\section{Cost Share and Profit Share}

Costs and Profit Share of Marketing Channel I in TebingTinggi Barat District in 2018 show that the total marketing costs in the channel I in Tebing Tinggi Barat District (can be seen in Table 6) are IDR2,499 $/ \mathrm{kg}$. The cost share obtained is $76.67 \%$. This means that the costs incurred per kilogram are a little expensive. Therefore, the cheaper costs are incurred, the more efficient the channel will be. The cost share and profit share obtained by the marketing institution can be seen in Table 6. The total cost share for the collectors is IDR517/ $\mathrm{kg}$ and the share profit is IDR $42 / \mathrm{kg}$, while the cost share for the wholesaler or refinery is IDR $1,982 / \mathrm{kg}$ and the profit obtained by them is IDR718 $/ \mathrm{kg}$. 


\section{Conclusions}

Based on the analysis results that have been described and pay attention to the research objectives that have been previously determined, the following conclusions are obtained:

1. The marketing channel for sago flour in TebingTinggi Barat District, KepulauanMeranti Regency consists of one marketing channel, namely marketing channel I, where farmers sell Tual sagu to the collectors, then the collectors sell to the wholesalers or refineries.

2. Seen from the barriers of entry and exit of the markets that are free of entry and perfect competition, the Tual sagu market structure in TebingTinggi Barat District, KepulauanMeranti Regency is leading to a perfectly competitive market.

3. The behavior of the Tual sagu market in TebingTinggi Barat District, KepulauanMeranti Regency leads to an imperfect competition market. There is a weak correlation between Tual saguselling prices at the farm level with of which at the factory level and the Tual sagu selling prices at the collectors' level with of which at the factory or refinery level. While the transmission of prices between markets at the farm level with of which at the factory or refinery level shows a price transmission coefficient larger than one, which means the rate of change in the Tual sagu prices at the farm level is greater than of which at the factory or refinery level.

4. Seen from the marketing margins, marketing costs and profits at each Tual sagu marketing agency in TebingTinggi Barat District, KepulauanMeranti Regency,the performance of the Tual sagu market in TebingTinggi Barat District shows the biggest profit by large traders or refineries that carry out more marketing functions by spending more marketing costs.

\section{Recommendations}

Suggestion the authors can point out in this study is Factories or refineries are expected to further implement marketing channels I to achieve a high level of profit, this is because if farmers use marketing channels II, farmers will sell tual sagu to collectors whose prices are too low that can give high profit margins too far between collectors and factories. Therefore, the mechanism on the marketing channel I must be further improved.

\section{References}

Anindita, R. \& N. Baladina. (2016). Pemasaran Produk Pertanian. Penerbit Andi. Malang

Azzaino, Z. (1981). Pengantar Tataniaga Pertanian. Diktat kuliah Sosial Ekonomi Pertanian IPB Bogor.

BPS Kabupaten Kepulauan Meranti. (2017). Kepulauan Meranti Dalam Angka 2017. BPS Kepulauan Meranti.

Dinas Perkebunan Dan Kehutanan Kabupaten Kepulauan Meranti. (2016). Perkebunan Kepulauan Meranti 2016. Kepulauan Meranti. Riau.

Elida, S. (2017). Pemetaan Pertanian Potensial Dalam Pengembangan Agroindustri Unggulan Di Kabupaten Kepulauan Meranti. Jurnal Agrotech, 3(1), 72-87.

Hay, \& Moris. (1991). Industrial Economic \& Organization, Theory \& Evidence. Second Edition.

Irawan. (1984). Saluran distribusi. http://www.dikmenum.go.id. Accessed on Monday, 16 April 2018.

Irawan, \& Wijaya. (2001). Saluran Pemasaran (Pertama). Yogyakarta: BPFE.

Kirana. (2003). Pengantar Ekonomi Industri: Pendekatan Struktur, Perilaku dan Kinerja Pasar. BPFE.Yogjakarta.

Kotler P. (2012). Marketing Management. 14th ed. Pearson: London. 
The Analysis of the Structure, Behavior, and Performance of Tual Sagu Market in Kepulauan Meranti District

Kuncoro, M. (2007). Ekonomika Industri Indonesia, Menuju Negara Industri Baru 2030. Yogyakarta: ANDI.

Kusnawan, K. \& Wijoyo, P. (2008). Pengaruh strategi bauran pemasaran (marketing mix) terhadap efektivitas volume penjualan sayuran hidroponik. AGRISE, 8(2), 97-103.

Marius, P. A. (1999). Dasar-Dasar Pemasaran (Pertama). Jakarta: Raja Grafindo Persada.

Mumbeya, P. N. (2011). A value chain and market integration analysis of the cassava market in the Democratic Republic of Congo. Tesis. Pretoria: University of Pretoria.

Navisa, S., Suwandari A. \& RidjalJ. (2014). Analisis Struktur Dan Perilaku Pasar Serta Kinerja Pasar Ubi Kayu di Desa Jambewungu Kecamatan Wringin Kabupaten Bondowoso.

Prasetyo, P. (2007). Hubungan Struktur Pasar dan Perilaku Pasar serta Pengaruhnya Terhadap Kinerja Pasar. Jurnal Ekonomi Pembangunan, 12, 111-122.

Ruhukail, L. N. (2012). Karakterisitik Petani Sagu dan Keragaan Serta Manfaat Ekonomi Sagu Bagi Masyarakat Dusun Waipaliti Desa Hitu Kecamatan Leihitu Kabupaten Maluku Tengah. Jurnal Agroforestri, VII(1), 65-72.

Saediman, H., S. A. A. Taridala. \& M. Ono. (2006). Sago marketing practises and problems: A survey of two Sago growing villages in Southeast Sulawesi. Agriplus, 16: 1-7.

Setiawan, B. (2010). Konsep dan Analisis Isue Kemiskinan dan Ketahanan pangan Masyarakat Pesisir. Makalah dalam Pelatihan metodologi Riset. Balai Besar Riset Sosial Ekonomi Kelautan dan Perikanan, Jakarta.

Sudiyono, A. (2001). Pemasaran Pertanian. Penerbit Universitas Muhammadiyah Malang (UMM Perss). Malang.

Taridala, S. \& Aida, A. (2006). Efisiensi Pemasaran Sagu (Metroxylon Sp.) di Kecamatan Ranomeeto, Kabupaten Konawe Selatan. Tidak Dipublikasi.

Teguh, M. (2006). Ekonomi Industri. Raja Graffindo, Jakarta.

Timisela, N. R., (2006), Analisis Usaha Sagu Rumah tangga dan Pemasarannya. Jurnal Agroforestri, 1(3), 57-64.

Umar, H. (2004). Metode Penelitian Untuk Skripsi dan Tesis Bisnis. Jakarta. PT Raja Grafindo Persada.

Wati, W. (2015). Analisis SCP (Strukture, Conduct, and Performance) Pasar Ojol Di Kecamatan Kampar Kiri Kabupaten Kampar. Skripsi. Jurusan Agribisnis Fakultas Pertanian Universitas Riau.

Yunika, N. (2009). Produk olahan sagu baik jajanan maupun makanan pokok. Jurusan Teknologi Hasil Pertanian. Fakultas Pertanian Universitas Muhammadiyah Sidoarjo. http://niceseafine.blogspot.com/2010/ety11/aneka-olahan-produk-pangan.html. [Diakses 24 Februari 2012]. 